\title{
Knowledge base and attitudes of university students towards complementary and alternative medicine (CAM)
}

\begin{abstract}
Introduction: The use of complementary and alternative medicine (CAM) is increasing in all parts of the UK. Based on the published data, CAM use appears to be more prevalent among patients attending the otolaryngology outpatient department who are in higher education cohort.
\end{abstract}

Aim: This study aims to establish the CAM use by university students and also explore their beliefs and knowledge base about the CAM.

\begin{abstract}
Methodology: Questionnaire based survey study.
Results: 450 questionnaires were distributed to students not studying medicine at Aberdeen University, of which 366 questionnaires were completed (81\% response rate). The proportion of students currently using CAM was $30.9 \%$ and $18.9 \%$ had used CAM in the last year. The most common information source to find out about CAM was family or friends $(52.2 \% ; n=191)$; whilst $41.8 \%(n=153)$ would recommend CAM to others. $44.5 \%$ $(n=163)$ spent $£ 9$ or less on CAM per week. The vast majority of students $(82.2 \% ; n=301)$, had not informed their GPs of their usage of CAM. Amongst the most common cited causes for CAM use was to help relieve exam stress.
\end{abstract}

Conclusion: CAM use is common amongst university students at our university and is likely to be the same in other institutions. Given the potential side effects of CAM and the possibility of drug-herb interaction, education on CAM should be made available on campus and students should be encouraged to report its use to their general practitioners.
Volume I Issue I - 2015

\author{
Rao G, Rao A, Pierce A, M Shakeel,Trinidade \\ A, Khan I,Ah-See KW \\ Department of otolaryngology-head and neck surgery, \\ Aberdeen Royal Infirmary, UK
}

Correspondence: M Shakeel FRCSED (ORL-HNS), Specialist Registrar, Otolaryngology-Head and Neck surgery, Ward 45,ARI, Aberdeen, AB25 2ZN, Tel 0044I224552100,

Email drshakeel@doctors.org.uk

Received:January 18, 2015 | Published: March 17, 2015

\section{Introduction}

The use of complementary and alternative medicine (CAM) is on the rise in the UK, and an estimated $£ 1.6$ billion is spent on it annually. Despite its escalating use, the distribution of CAM is still largely unregulated. This is partly due to the current legislation which does not require CAM therapies to go through the rigorous clinical testing that conventional medicines must do prior to marketing and merchandising to the public. ${ }^{1}$ There are many possible concerns with respect to this. In one survey of the prescribing practices of 323 Scottish GP offices over a one year period, $60 \%$ of the practices were found to prescribe herbal medicines and $4 \%$ of patients had been administered herbal medicines known to interact with the patients' current prescribed conventional drugs. ${ }^{2}$

Our hospital is affiliated with the local university, and in out ENT Department, we noticed that many university students admitted to having used CAM at least once. It is often the perception of medical practitioners that only the 'poorly educated' would resort to CAM. To date we have been unable to find any previous studies from the United Kingdom that have looked at the consumer behavior and use of CAM by university students, who could be considered recipients of 'higher education' and therefore perhaps more enlightened to conventional medicine. The aim of our study was to establish the CAM use by university students and also explore their beliefs and knowledge base about the CAM.

\section{Methods}

This was a questionnaire-based survey study and was conducted over a 4-week period. The questionnaire was developed by the team based on previously published literature and was piloted before use in the current study. It included a brief definition of complementary and alternative medicine and highlighted therapies that come under this umbrella term (Appendix 1). Questionnaires were distributed to the university students with the exclusion of medical students. One of the researchers was always available to distribute and collect the questionnaire face to face to allow any queries to be answered if needed. A total of 450 questionnaires were distributed. Each responder completed the questionnaire only once. The questionnaires were distributed to the university students.

The data were entered into a prospective spreadsheet on Microsoft Excel 2007 and analyzed using SPSS 15. Descriptive statistics were calculated for the cumulative data on the whole sample for quantitative variables and frequencies.

\section{Results}

The response rate was $81 \%$ (366/450). Most students were undergraduates $(n=295)$ and there was a slightly higher number of females overall $(\mathrm{n}=200,56 \%)$. Most students were aged 20 to 21 $(\mathrm{n}=120,33.9 \%)$ (Table 1$)$. The most commonly used non-herbal CAM was massage ( $n=44,15 \%)$, followed by aromatherapy and counseling (Table 2). With respect to herbal CAM, energy drinks were most 
commonly used $(\mathrm{n}=133,45.2 \%)$ followed by vitamins and aloe vera (Table 3). The most common reasons to use herbal treatments were to provide energy boost, aid in exercise and exams and to increase concentration. At the time of study, approximately $31 \%$ of students $(\mathrm{n}=113)$ were currently using some form of CAM. Almost one third of students had never tried CAM ( $\mathrm{n}=114,31 \%)$ (Table 4). Most students gained information about CAM from family and friends $(\mathrm{n}=191$, $52 \%$ ), whilst the media and the internet also proved popular (Figure 1). Up to almost $18 \%$ of students $(n=64)$ had received advice on CAM from a healthcare professional (Table 4). Despite its level of use in the student population, most students $(\mathrm{n}=195,53 \%)$ were unsure of its effectiveness and its safety $(\mathrm{n}=207,57 \%)$ (Figures $2 \& 3$ ), but only 65 students admitted that their GPs knew about their CAM usage and almost $42 \%(n=153)$ would recommend its use to others nonetheless. Sixty students $(16 \%)$ were also on prescribed medications. Of those who bought CAM, most would not spend more than $£ 10$ on it $(n=163$, $45 \%$ ), whilst 2 students admitted to spending over $£ 50$ (Table 4 ).

Table I Study sample characteristics

\begin{tabular}{lcc}
\hline $\begin{array}{l}\text { Participants } \\
\text { characteristics }\end{array}$ & $\begin{array}{c}\text { n(number of } \\
\text { participants) }\end{array}$ & Percentage(\%) \\
\hline Total & 366 & 100 \\
Gender & 166 & 44.2 \\
Male & 200 & 55.8 \\
Female & \\
Level of university course & 81 \\
Undergraduate & 295 & 19 \\
Post graduate & 71 & \\
Age & 110 & 30.4 \\
$<19$ & 120 & 33.9 \\
$20-21$ & 60 & 16.2 \\
$22-23$ & 76 & 19.5 \\
$>24$ &
\end{tabular}

Table 2 Reasons for use of Non-herbal CAM by university students

\begin{tabular}{lcl}
\hline Non-Herbal Therapy & $\mathbf{n}(\%)$ & $\begin{array}{l}\text { Reasons } \\
\text { Massage }\end{array}$ \\
$\begin{array}{ll}\text { Aromatherapy } \\
\text { Counselling }\end{array}$ & $36(12.2)$ & $\begin{array}{l}\text { Musculoskeletal pain, Relaxation, } \\
\text { Stress }\end{array}$ \\
Meditation & $21(7.1)$ & Depression, Sleep, Stress \\
Acupuncture & $21(7.1)$ & Relaxation, Stress, Family advice \\
Bach Therapy & $16(5.4)$ & Musculoskeletal pain, cold \\
Chiropractor & $15(5.1)$ & Exams, Stress, Anxiety \\
Spiritual healing & $12(4.1)$ & Musculoskeletal pain, relaxation \\
Reflexology & $6(2)$ & Headache, psychological help \\
Osteopathy & $5(1.7)$ & Family advice, Stress, Relaxation \\
\hline
\end{tabular}

Table Continued..

\begin{tabular}{lcl}
\hline \multicolumn{1}{c}{ Non-Herbal Therapy } & $\mathbf{n}(\%)$ & Reasons \\
\hline Kinesiology & $3(\mathrm{I})$ & Musculoskeletal pain, Headache \\
Shiastu & $3(\mathrm{I})$ & Musculoskeletal pain, Stress \\
Kinesiology & $3(\mathrm{I})$ & Musculoskeletal pain, Headache \\
Kinesiology & $3(\mathrm{I})$ & Musculoskeletal pain, Headache \\
$\begin{array}{l}\text { Anthrophilosophical } \\
\text { Medicine }\end{array}$ & $\mathrm{I}(0.3)$ & None mentioned \\
\hline
\end{tabular}

Table 3 Reasons for use of Herbal(CAM) Therapies by university students

\begin{tabular}{|c|c|c|}
\hline Herbal Therapies & $n(\%)$ & Reasons \\
\hline Energy Drinks & $133(45.2)$ & $\begin{array}{l}\text { Energy boost, Exercise, Increase } \\
\text { concentration, Exams }\end{array}$ \\
\hline Vitamins & $120(40.8)$ & $\begin{array}{l}\text { Nutritional support, Boost immunity, } \\
\text { General health, Constipation } \\
\text { Skin }\end{array}$ \\
\hline Alovera & $52(17.7)$ & $\begin{array}{l}\text { rash), Hair/nail treatment, General } \\
\text { health }\end{array}$ \\
\hline Echinacea & $26(8.8)$ & $\begin{array}{l}\text { Cold/flu/fever, Boost immunity, } \\
\text { General health } \\
\text { General health, prevent }\end{array}$ \\
\hline Cranberry Juice & $32(10.9)$ & $\begin{array}{l}\text { infection(urine infection in particular), } \\
\text { gastro-intestinal symptoms }\end{array}$ \\
\hline Protein Supplements & $31(10.5)$ & Exercise,Weight gain, Exams \\
\hline Garlic & $28(9.5)$ & $\begin{array}{l}\text { Cold/flu, Boost immunity, General } \\
\text { health }\end{array}$ \\
\hline Homeopathy & $19(6.5)$ & $\begin{array}{l}\text { Cold/flu, Skin problems(eczema, } \\
\text { sunburn, rash), Musculoskeletal pain }\end{array}$ \\
\hline Herbal Vitamins & $2 \mathrm{I}(7.1)$ & $\begin{array}{l}\text { Nutritional Support, General Health, } \\
\text { Cold/flu }\end{array}$ \\
\hline Ginseng & $12(4.1)$ & $\begin{array}{l}\text { Energy boost, Exams, General health, } \\
\text { Nutritional support }\end{array}$ \\
\hline Primrose Oil & $12(4.1)$ & $\begin{array}{l}\text { Menstrual symptoms, Menopausal } \\
\text { symptoms, General health, Skin } \\
\text { problems(eczema, sunburn, rash) }\end{array}$ \\
\hline Minerals & $20(4.8)$ & Nutritional support, General health \\
\hline Chinese Herbal Medicine & $18(6.1)$ & Cold/flu, General health, sleep \\
\hline Creatine & $18(6.1)$ & Exercise, Exams, Nutritional support \\
\hline Weight loss products & $18(6.1)$ & General health, Weight loss \\
\hline Gym Enhancer & $15(5.1)$ & $\begin{array}{l}\text { Exercise, General Health, } \\
\text { Musculoskeletal pain }\end{array}$ \\
\hline St John Warts & $10(3.4)$ & Stress, Depression \\
\hline Ginkgo & $9(3.1)$ & $\begin{array}{l}\text { Increase memory, Exams, Energy } \\
\text { boost }\end{array}$ \\
\hline Glucosamine & $8(2.7)$ & Musculoskeletal pain, Exercise \\
\hline Ayurvedic Medicine & $6(2)$ & $\begin{array}{l}\text { General health, Constipation, Gastro- } \\
\text { intestinal symptoms }\end{array}$ \\
\hline Glutamine & $4(1.4)$ & $\begin{array}{l}\text { Musculoskeletal pain, Exercise, } \\
\text { Psychological help }\end{array}$ \\
\hline Melatonin & $4(1.4)$ & Psychological help, Sleep \\
\hline Kava & $2(0.7)$ & Enjoyment, Family advice \\
\hline Ephedra & $\mathrm{I}(0.3)$ & Exercise, To stay awake \\
\hline Eastern Medicine & $\mathrm{I}(0.3)$ & Enjoyment \\
\hline Naturopathy & $\mathrm{I}(0.3)$ & Relaxation \\
\hline
\end{tabular}


Table 4 Exploration of students' attitude towards CAM

\begin{tabular}{ll}
\hline Use of CAM & \multicolumn{1}{c}{$\begin{array}{c}\text { University } \\
\text { students } \mathbf{n}(\%)\end{array}$} \\
\hline Currently & $113(30.9)$ \\
Yes, <lyear & $69(18.9)$ \\
Yes, > Iyear & $54(14.8)$ \\
Never & $114(31.1)$ \\
Information Source on CAM & \\
Media & $81(22.1)$ \\
Health care professional & $64(17.5)$ \\
Family/friends & $191(52.2)$ \\
Books & $27(7.4)$ \\
Internet & $68(18.6)$
\end{tabular}

\section{Perceived effectiveness of CAM}

Not Effective

Less Effective

$18(4.9)$

Not sure

Very Effective

Extremely Effective

\section{Perceived safety of CAM}

Very unsafe

Quite unsafe

Not sure

Quite safe

Very safe

Recommend CAM use to others

I53(4I.8)

\section{Exercise Routine}

Less than 4 times

2-4 times

136(37.2)

106(29)

63(17.2)

$88(24.0)$

$65(17.8)$

GP knowledge about CAM use

Money spent on CAM

Nil

169(46.2)

$<9$ GBP

I63(44.5)

10-19 GBP

25(6.8)

20-49 GBP

$7(1.9)$

$>50$ GBP

Administration of Prescribed Medicine
$2(0.5)$

$60(16.4)$

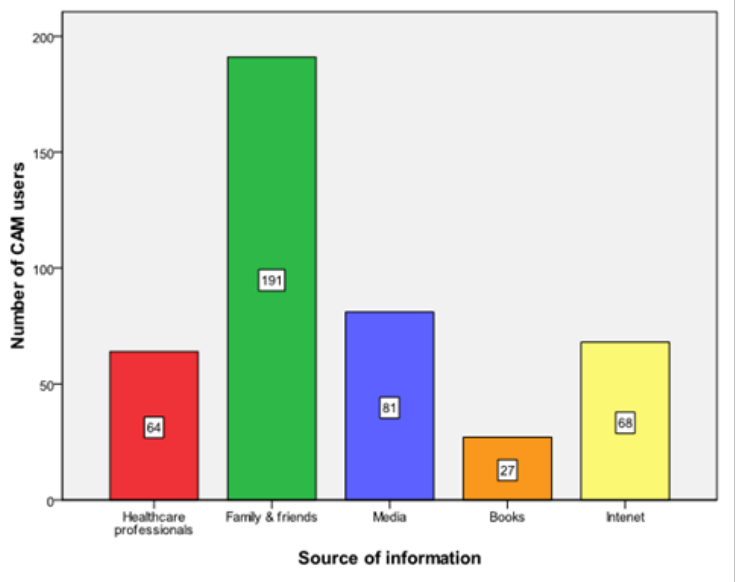

Figure I Sources of information on Complementary and Alternative Medicine consulted by university students.

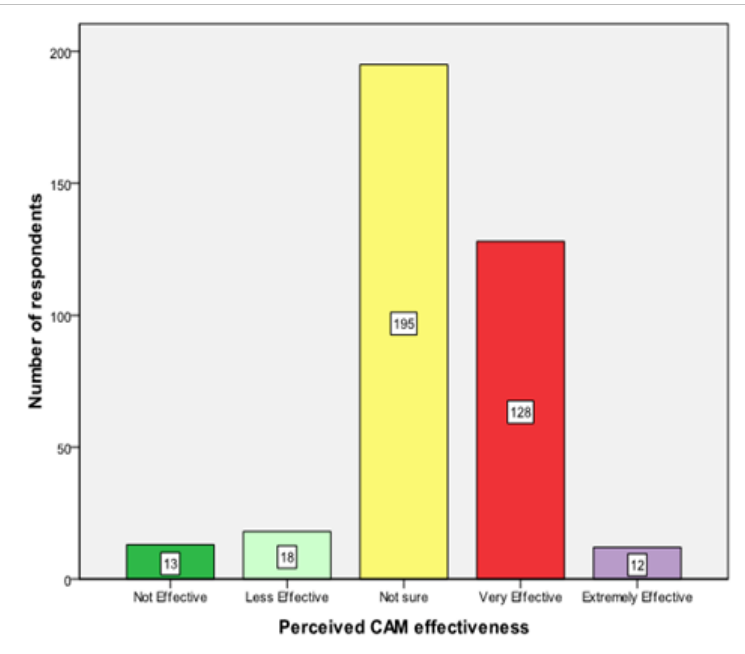

Figure 2 Perceived effectiveness of Complementary and Alternative Medicine by university students.

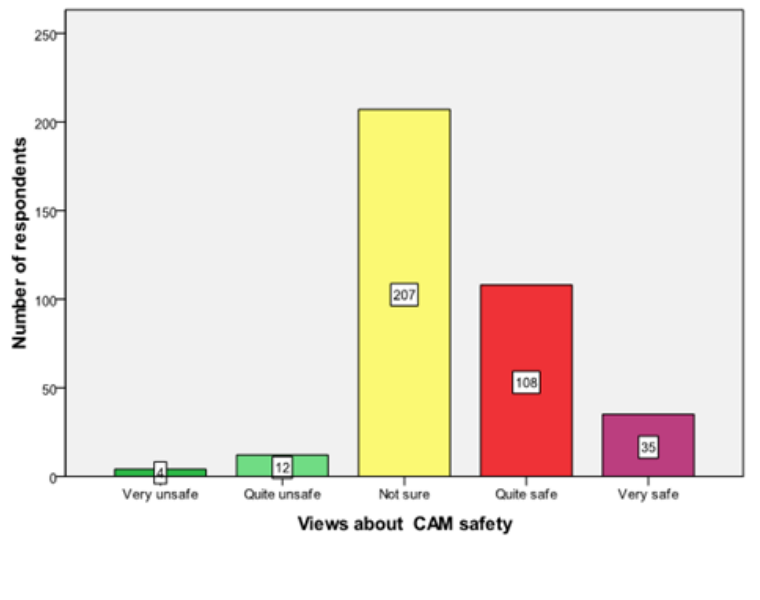

Figure 3 Perceived safeties of Complementary and Alternative Medicine by university students. 


\section{Discussion}

It is clear from our research that CAM use is prevalent amongst our local university student population, a finding that is likely to be translatable to university student populations at large. There are several possible reasons for this. People's therapy choice may be influenced by an adoption of a healthy living regime. Many feel that CAM therapies offer a more natural option which more fits in to this 'healthier' lifestyle when compared to more conventional therapies. Another theory of consumer behavior regarding CAM have shown that many people turn to using alternative therapies once they have already tried conventional medical therapy. Factors influencing their choices included severity of symptoms, consumer age, and dissatisfaction with conventional care. ${ }^{3}$

It is patients with chronic conditions such as arthritis, malignancies and dementia that are most commonly quoted as using CAM. This differs from our results with almost two-thirds of our group being aged 22 or below and therefore having a lower prevalence of chronic illness. Overall, when comparing these students to a non-medical, non-student population previously studied Shakeel et al. ${ }^{1}$ we found that the students were as likely to have found CAM effective and also as likely overall to recommend CAM use to others. These finding add to the hypotheses that university students and the public are similar in their views and usage of CAM despite the perception of them being 'more highly educated'. Similar high CAM usage was found in university students in the USA and Canada. 4,5

The findings of this study correlate well with previous studies that have looked into the differences between the sexes and use of CAM ${ }^{6}$ Our study also highlights the cost of using CAM within the student population. We found that almost half of participants regularly spent money on CAM, most spending $£ 9$ or less a week. This shows that CAM usage is not necessarily reserved for those who are 'well-off'.

It is interesting that despite the prevalence of students using CAM most were unsure of both its effectiveness and its safety. Yet most would still recommend its use and very few made their GP aware that they were using it. This highlights the misconception that CAM is generally safe to use, a misconception that has probably kept its distribution largely unregulated until recently. In general we found that knowledge of the potential side effects and drug-herb interactions was lacking amongst the student population. As a result, most did not think it important to tell their GPs of its usage, despite many using prescribed medications.

\section{Conclusion}

CAM use is common amongst university students at our university and is likely to be the same in other institutions. Given the potential for unaccounted for side effects and the possibility of drug-herb interaction, education on CAM should be made available on campus and students should be encouraged to report its use to their general practitioners

\section{Acknowledgments}

None.

\section{Conflicts of interest}

The authors declare there are no conflicts of interest related to the article.

\section{Funding}

None.

\section{References}

1. Novella S, Roy R, Marcus D, et al. A Debate:Homeopathy-Quackery or a Key to the Future of Medicine? J Altern Complement Med. 2008;14(1):915 .

2. Shakeel M, Trinidade A, Ah-See KW. Complementary and alternative medicine use by otolaryngology patients:a paradigm for practitioners in all surgical specialties. Eur Arch Otorhinolaryngol. 2010;267(6):961971.

3. Featherstone C, Godden D, Gault C, et al. Prevalence study of concurrent use of complementary and alternative medicine in patients attending primary care services in Scotland. Am J Public Health. 2003;93(7):1080 1082.

4. Sirios FM, Purc-Stephenson RJ. Consumer decision factors for initial and long-term use of complementary and alternative medicine. Complement Health Pract Rev. 2008;13(1):3-19.

5. Johnson SK, Blanchard A. Alternative medicine and herbal use among university students. J Am Coll Health. 2006;55(3):163-168.

6. Teper AM, Tsai E. Complementary and alternative medicine use by Canadian university students. Can J Clin Pharmacol. 2008;15(1):e5-e14.

7. Hedderson MM, Patterson RE, Neuhouser ML, et al. (2004) Sex differences in motives for use of complementary and alternative medicine among cancer patients. Altern Ther Health Med. 2004;10(5):58-64. 